\title{
IN MEMORIAM: JOHANN SEBASTIAN BACH $(1685-1750)$.
}

Dit was op 28 Julie 1.l. presies tweehonderd jaar gelede dat Bach in Leipzig gesterf het-blind maar werksaam tot amper aan sy einde. Die toestand van sy oë was vir hom 'n lewenslange kwelling. Hy was bysiende en die onvermoeide ywer waarmee hy voortdurend met komposisic, hersiening en kopieëerwerk sy oë ingespan het, het in sy laaste jare 'n pynlike oogaandoening ten gevolge gehad. „Uit die begeerte om God en sy naaste met sy ongeskonde liggaamlike en geestelike kragte nog verder te dien," (1) het hy twee pynlike operasies aan sy oë ondergaan, wat albei misluk het. Hy het blind geword en sy sterk liggaamsbou is tot

(1) Nekrologie, bls. 167. 
so 'n mate ondermyn dat hy nooit weer ten volle herstel het nie en langsaam weggekwyn het. Sy laaste dae moes hy in 'n heeltemal verdonkerde kamer deurbring, waar hy aan sy skoonseun, Altnikol, 'n koraalfantasie op die koraalmelodie „Wenn wir in höchsten Nöten sind" dikteer het. Hy het dit laat aanvang met die lied „Vor deinen Tron tret' ich alhier" wat op dieselfde wysie gesing word. Hierdie laaste meesterwerk, voltooi in die skadu van die dood, is sonder weemoed of verdriet. Dit vloei kalm en rustig en is gehul in 'n transfigurerende lig. Een oggend was sy gesig skielik herstel en kon sy oë selfs lig verdra. 'n Paar uur later is hy getref deur' $n$ aanval van beroerte, hoë koors het ingetree en op 28 Julie 1750 het hy in die aand stil en rustig heengegaan. Drie dae later is hy in die kerkhof aan die St. Johannes-kerk ter aarde bestel.

Sy heengaan is algemeen betreur en uit vele oorde is sy lof besing, sonder dat sy tydgenote egter werklik enige begrip van sy grootheid gehad het. Hulle het in hom geroem die beroemde orrelis en die groot meester van die polifoniese vorms, die teoretikus en deskundige op die gebied van wat beskou is as 'n uitgediende styl. In 'n tydperk van nuwe filosofiese strominge (die rasionalisme en die van ,terug na die Natuur"), van 'n nuwe, meer „ekspressiewe," homofoniese styl, van „galantheid" en van 'n selfbewuste skoonheidsleer, het hy hulle as 'n anachronisme voorgekom. Inderdaad, hulle het reg gehad. Bach het geleef in die eeu, maar hy was nie van die eeu nie. Sy kuns wortel diep verankerd in die Duitse Hervorming en in die meerstemmige styl van die sestiende ecu. Maar dit is ook gevoed deur die beste wat die sewentiende eeu opgelewer het-daardie eeu van omwenteling in die Musiekgeskiedenis, van sekularisasie van die toonkuns, toe skeppende kunstenaars in Italië, Frankryk, Engeland en gaandeweg ook in Duitsland hul verlustig het in ' $n$ weelde van nuwe vokale en instrumentale vorms en style. Sy kuns is 'n magtige sintese van wat vooraf gegaan het, 'n reuse katedraal van klank, byna Goties in sy majesteit en in die geheimsinnige krag en skoonheid wat daaruit straal. Vele invloede uit vele bronne, uit Renaissance en Barok, het hierdie kuns help vorm. Nougesette stylkritiek, gepaard met historiese navorsing kan seker veel verrig om dit wetenskaplik te ontleed en te verklaar, maar die uiteindelike geheim van die byna bomenslike tegniek en van sy veredelende invloed op die gemoed, bly raaiselagtig en onverklaarbaar, buite bereik van wetenskaplike metodes.

Daar gaan egter wel lig op as hierdie kuns benader word vanaf Bach, die mens. Hy was 'n gelowige, diep onder indruk van sy menslike swakheid en sondigheid, juigend in die gewisse sekerheid van die salig- 
makende genade van die Verlosser, vol vertroue in 'n ewige lewe na die dood. Sy kuns getuig van hierdie onwrikbare geloof. Mens hoef slegs te verwys na sy toonsetting van die Credo in sy monumentale Mis in B-mineur, veral na die geloofsartikels van kruisiging en opstanding wat selfs vir die oningewyde luisteraar 'n ondubbelsinnige taal spreek; na die majesteit van die Sanctus in dieselfde werk wat selfs by die ongelowige eerbied en respek afdwing; na die byna tweehonderd kantates wat bewaar gebly het: diepsinnige meditasies oor heilige dinge, uitings van 'n hart tot sy God gekeer; na die Mattheüs-passie, deurdrenk van eerbiedige, gelowige gesindheid; na die diepsinnige koraalvoorspele vir die orrel, die vrug van liefdevolle bepeinsing oor gewyde poësie.

As verdere getuienis van godvrugtige lewenswandel nodig is, spreek sy eie woorde ook nog tot ons uit sy manuskripte en uit die voorwoorde tot sommige publikasies. Bo-aan staan dikwels "Jesu juva”; onderaan, „Soli Deo Gloria." Musiek was klaarblyklik vir hom 'n godsdiensoefening. Hy het 'n Kalvinistiese siening van die toonkuns gehad: uit God-tot God. Uit die reëls en beginsels vir begeleiding wat hy vir sy leerlinge neergelê het, vertaal ek die volgende sinnetjie: „alle musiek . . . behoort geen ander doel of strewe te hê as die glorie van God en die ontspanning van die siel nie; waar dit nie in gedagte gehou word nie is daar geen ware musiek nie, maar net 'n verfoeilike lawaai en bombas." Vooraan in sy „Orgelbüchlein" staan die volgende spreukie: (ek vertaal)

Die Allerhoogste God alleen tot eer;

My naaste daaruit te beleer.

Vir hom val ook die musikale opvoeding in die terrein van die godsdiens. By die eerste klavierstukkies wat hy vir die opleiding van sy oudste seun gekomponeer het, staan: „In nomine Jesu." Trouens, sy hele lewens- en kunsbeskouing was fundamenteel godsdienstig georiënteerd. In die inventaris van sy eiendom, na sy dood saamgestel, staan die name van 'n groot aantal teologiese werke waaronder 'n volledige uitgawe van Luther se werke en die preke van Tauler.

As al hierdie feite in gedagte gehou word, kom dit ook byna as iets vanselfsprekends voor dat Bach as kunstenaar uniek was in sy beskeidenheid. Hy is nie alleen die grootste Protestantse toonkunstenaar nie, hy is een van die allergrootste in die geskiedenis. Deur vele word hy beskou as die grootste komponis wat die wêreld nog geken het. Wat van hom opnuut 'n unieke persoonlikheid maak is die feit dat hy nie van sy eie grootheid bewus was nie. Sy massas vokale en instrumentale 
musiek is nie geskryf „vir die nageslag nie" of vir „dié wat sal verstaan" nie. Dit het ontstaan in die loop van sy daaglikse werk as orrelis, kantor of kapelmeester, of op bestelling, of om die patronaat van 'n invloedryke prins te verwerf. Die grootste deel van sy musiek het hy in die uitvoering van sy kerklike pligte gelewer. Niemand was seker minder bewus as hy dat sy werk deur die eeue heen sou klink nie, dat dit spreekwoordelik sou word as 'n toetssteen van artistieke meesterskap en onpeilbare diepte. In hierdie opsig munt hy moontlik bo alle ander skeppende kunstenaars uit. Sy enorme skeppende vermoë het gefunksioneer sonder enige selfbewustheid, soos 'n natuurkrag, allesomsluitend en oorvloedig. In sy verhewe konsepsies aangaande die doel en wese van die toonkuns was daar geen ruimte vir egosentriese selfverheerliking deur middel van die kuns nie; geen roekelose ambisie om die glorieryke voorwerp van die aanbidding van onnadenkende menigtes te word nie. In dié opsig val hy in geen kategorie nie. Hy staan alleen.

$\mathrm{Na}$ sy dood het sy werke die prooi van 'n bykans algehele verwaarlosing geword. Eers teen die helfte van die daaropvolgende eeu het die groot Bachherlewing begin met uitvoerings van sy groot vokale werke en met langvertraagde navorsing. Vandag is die "Bach-Renaissance” nog in volle swang. in Paar van die groot werke het al as 't ware gemeenskapsbesit geword en 'n verteenwoordigende hoeveelheid van die instrumentale musiek is al in die gangbare repertorium opgeneem. Net die Kerk, aan wie se diens en glorie hy sy lewe gewy het, neem nog veels te min notisie van hom.

Moontlik is die posisie in Suid-Afrika in hierdie verband nog veel meer betreurenswaardig as in ander lande. Enkele orreliste wat hulle met die beste bedoelings aan sy orrelwerke waag, word feitlik net geduld en veelal met agterdog en selfs met mis noeë bejeën. Koorleiers toon nog weinig inisiatief in die ontginning van die onvergelyklike erfenis van sy kantates, wat die kosbaarste besit van die Reformatoriese Kerke is. Vir die meeste kerkgangers is hy nouliks 'n naam.

Ons is ryk en ons misken ons rykdom.

Dit kan die gevolg wees van vrees vir die ,onbekende" of dit kan die gevolg wees van blote lamlendigheid. Ek vrees egter dat die diepere gronde daarvoor gesoek moet word eerstens, in die euwel van skaamtelose onverskilligheid wat al byna tiperend van hierdie geslag geword het en wat op alle vertakkings van ons geestelike lewe inwerk; tweedens, in die laakbare onkunde oor die toonkuns en sy grootste meesters, sowel as ' $n$ verlustiging in hierdie onkunde, wat noual selfs by hoogopgevoede mense „mode" geword het. 
Op so 'n pessimistiese toon hoef egter gelukkig nie afgesluit te word nie. Daar bestaan rede vir optimisme op grond van die persberigte aangaande die stigting van 'n Suid-Afrikaanse Bachvereniging en onlangs weer aangaande die stigting van 'n Afrikaanse Kerkmusiekvereniging, beide met omvangryke programmas en aangevuur deur 'n hoë idealisme. Hierdie verenigings neem 'n groot en gewigtige taak op hulle skouers en "Koers" wil dan ook van hierdie geleentheid gebruik maak om hulle alle heil en vrug op hulle arbeid toe te wens. Die opheffing van ons Kerkmusiek tot eer van God hang ten nouste saam met die toeëiening van ons Bach-erfenis. Mag daar 'n seën op hierdie ondernemings rus! Dan sal vir die Kerk van die toekoms moontlik nog 'n nuwe era van Kerkmusiek vanaf hierdie Bach-herdenkingsjaar dagteken!

J. P. MALAN. 